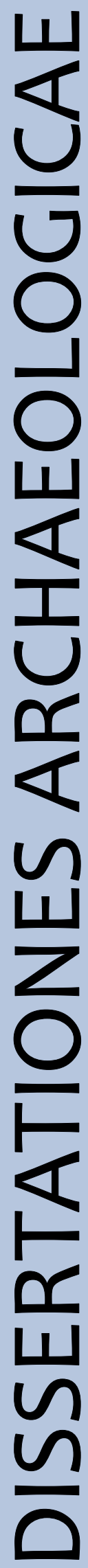

ex Instituto Archaeologico Universitatis de Rolando Eötvös nominatae
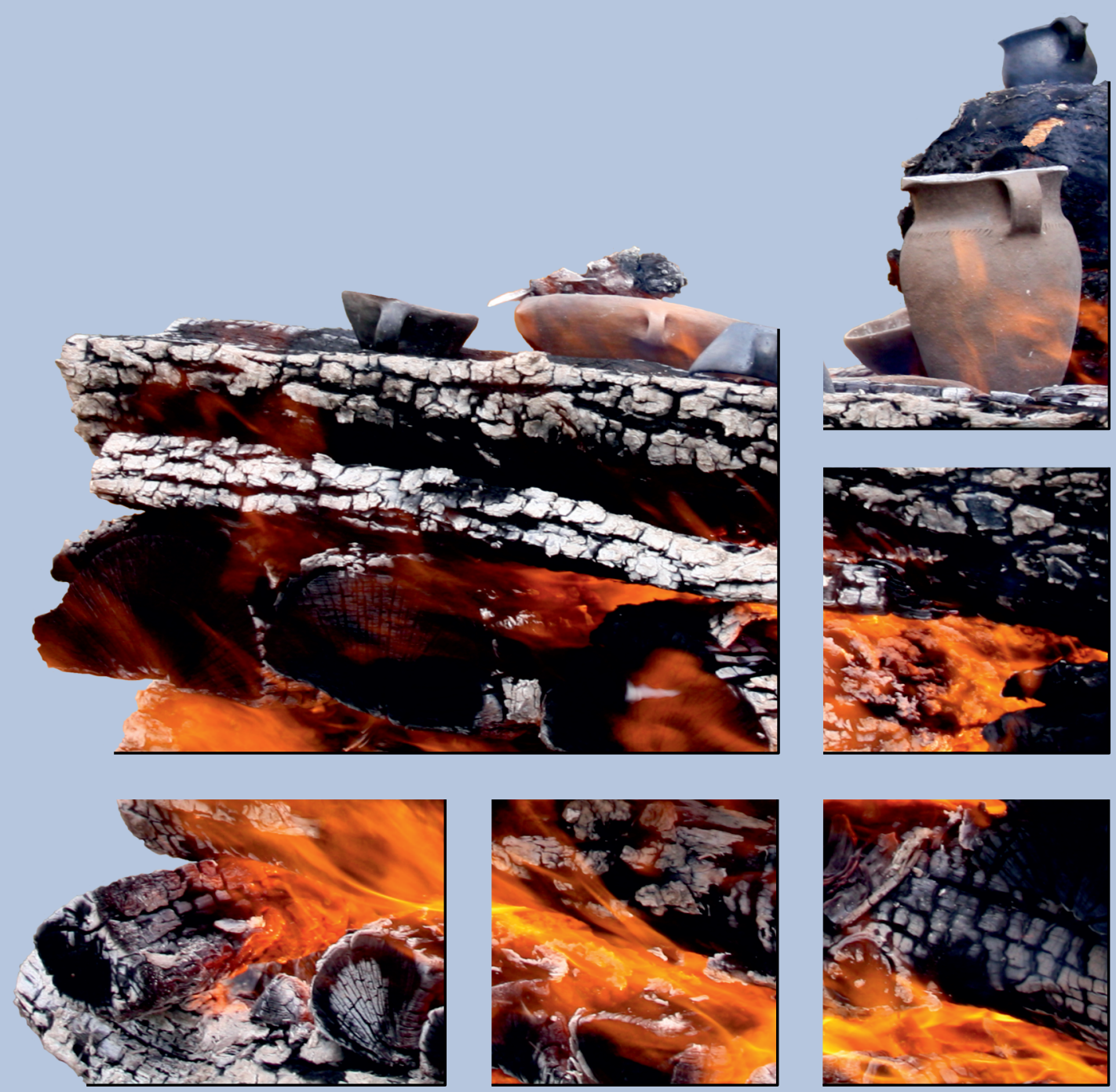

$$
\text { Ser。 3. No } 0_{0} \sigma_{0} \mid 2018
$$




\section{Dissertationes Archaeologicae ex Instituto Archaeologico}

Universitatis de Rolando Eötvös nominatae Ser. 3. No. 6.

Budapest 2018 


\section{Dissertationes Archaeologicae ex Instituto Archaeologico}

Universitatis de Rolando Eötvös nominatae Ser. 3. No. 6.

Editor-in-chief:

DÁvid BARTUS

Editorial board:

LÁsZló BARTOSIEWICZ

LÁSZLÓ BORHY

ZOLTÁN CZAJLIK

ISTVÁN FELD

GÁBOR KALLA

PÁL RACZKY

MiKLÓS SZABÓ

Tivadar Vida

Technical editor:

GÁBOR VÁcZI

Proofreading:

ZsófIA KondÉ

SzILVIA BARTUS-SzÖLLősI

Aviable online at http://dissarch.elte.hu

Contact: dissarch@btk.elte.hu

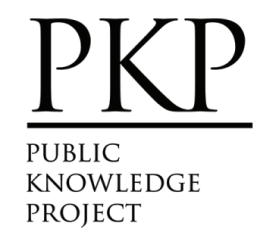

๑ E Eötvös Loránd University, Institute of Archaeological Sciences

Layout and cover design: Gábor Váczi

Budapest 2018 


\section{CONTENTS}

Zsolt Mester

In memoriam facques Tixier (1925-2018)

\section{ARTICLES}

Katalin SEBőK

On the possibilities of interpreting Neolithic pottery - Az újkökori kerámia értelmezési lehetőségeiről

András FüZESI - Pál RACZKY

Öcsöd-Kováshalom. Potscape of a Late Neolithic site in the Tisza region

Katalin SEBőK - Norbert FARAgó

Theory into practice: basic connections and stylistic affiliations of the Late Neolithic settlement at Pusztataskony-Ledence 1

Eszter Solnay

Early Copper Age Graves from Polgár-Nagy-Kasziba

László GuCsi - Nóra Szabó

Examination and possible interpretations of a Middle Bronze Age structured deposition

Kristóf FÜLÖP

Why is it so rare and random to find pyre sites? Two cremation experiments to understand the characteristics of pyre sites and their investigational possibilities

Gábor János TARBAY

"Looted Warriors" from Eastern Europe

Péter MogYoRós

Pre-Scythian burial in Tiszakürt

Szilvia JoHÁczi

A New Method in the Attribution? Attempts of the Employment of Geometric Morphometrics in the Attribution of Late Archaic Attic Lekythoi 
The Roman aqueduct of Brigetio

Lajos JuHÁsz

A republican plated denarius from Aquincum

Barbara HAJDU

Terra sigillata from the territory of the civil town of Brigetio

Krisztina HoppÁL - István VIDA - Shinatria AdHityatAma - Lu Yahui 461

'All that glitters is not Roman'. Roman coins discovered in East Java, Indonesia.

A study on new data with an overview on other coins discovered beyond India

\section{FIELD REPORTS}

Zsolt MESTER - Ferenc CSERPÁK - Norbert FARAGÓ

Preliminary report on the excavation at Andornaktálya-Marinka in 2018

Kristóf FÜLÖP - Denisa M. LÖNHARDT - Nóra SZABÓ - Gábor VÁcZI

Preliminary report on the excavation of the site Tiszakürt-Zsilke-tanya

Bence Simon - Szilvia JohÁcZI - Zita KIS

Short report on a rescue excavation of a prehistoric and Árpádian Age site near Tura

(Pest County, Hungary)

Zoltán CzAJlik - Katalin NovinszKi-Groma - László RupNIK - András BöDőcs - et al. 527

Archaeological investigations on the Süttö plateau in 2018

Dávid BARTus - László BORHY - Szilvia JoHÁczi - Emese SzÁMADó

Short report on the excavations in the legionary fortress of Brigetio (2017-2018)

Bence Simon - Szilvia JoháczI

Short report on the rescue excavations in the Roman Age Barbaricum near Abony

(Pest County, Hungary)

Szabolcs Balázs NAGY

Recent excavations at the medieval castle of Bánd 


\section{Thesis Abstracts}

Rita JENEY

Lost Collection from a Lost River: Interpreting Sir Aurel Stein's "Sarasvatī Tour" in the History of South Asian Archaeology

István VIDA

The Chronology of the Marcomannic-Sarmatian wars. The Danubian wars of Marcus Aurelius in the light of numismatics

Zsófia MASEK

Settlement History of the Middle Tisza Region in the $4^{\text {th }}-6^{\text {th }}$ centuries AD.

According to the Evaluation of the Material from Rákóczifalva-Bagi-földek 5-8-8A sites

Alpár Doвоs

Transformations of the human communities in the eastern part of the Carpathian Basin between the middle of the $5^{\text {th }}$ and $7^{\text {th }}$ century. Row-grave cemeteries in Transylvania, Partium and Banat 


\title{
Pre-Scythian burial in Tiszakürt
}

\section{PÉTER MOGYORÓS}

Institute of Archaeological Sciences

Eötvös Loránd University

mogyipeti5@gmail.com

\begin{abstract}
During its long history, humanity left traces everywhere, therefore it is inevitable that finds, hoards or burials are going to be found accidentally besides professional excavations. That kind of a discovery occurred in Tiszakürt (Hungary), where a grave of the Mezöcsát group has been found.

In this paper the three vessels - two urns and a beaker - of the grave will be presented. We do not have the skeleton, however, we do have an exquisite description of the grave. This description is important since it allows us to examine the burial practice as well.
\end{abstract}

\section{The Discovery}

In the May of 1995, in Tiszakürt, on the right shore of the present-day river Tisza, $25 \mathrm{~km}$ north of Csongrád in Jász-Nagykun-Szolnok County (Fig. 1), László Tálas was occupied with the building of his house. During the preliminary work of the foundation a skeleton and pottery shards appeared. He collected the shards and the bones he found. Unfortunately, the area of the foundation did not cover the whole grave, and some parts of the legs were outside of it.

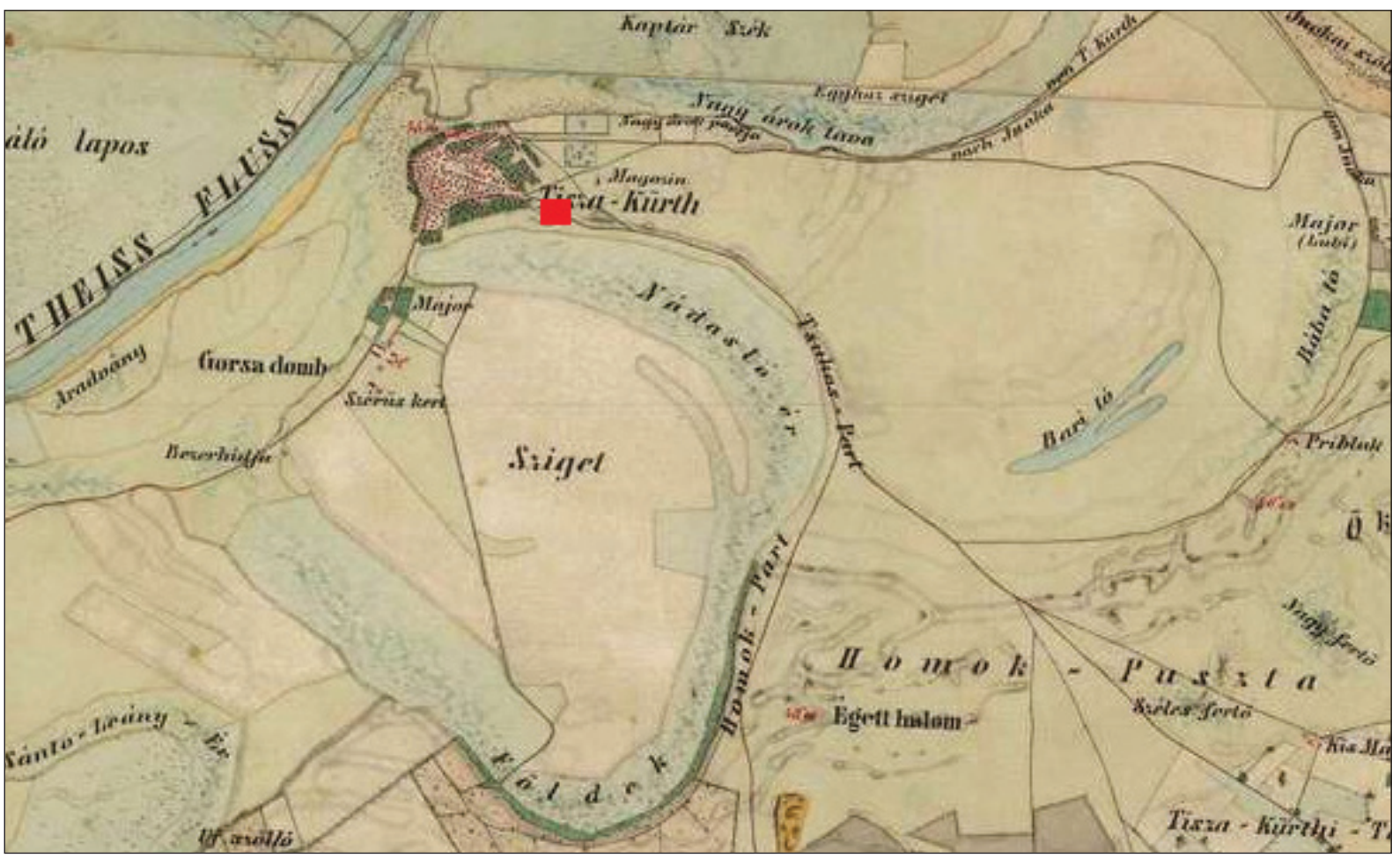

Fig. 1. The location of the grave and the surrounding region on a map of the Second Military Survey of the Habsburg Empire (1819-1869). 
As the risk of the destruction of the bones was too high, some parts are still under the ground. During the summer of 2018, the Institute of Archaeological Sciences of the Eötvös Lóránd University carried out an excavation prior to the construction of the M44 motorway near Tiszakürt. László Tálas took this opportunity, and gave the pottery finds to the Institute along with his description on the grave. ${ }^{1}$

\section{Description}

\section{Description of the grave ${ }^{2}$}

The grave appeared at a depth of 60-70 $\mathrm{cm}$. Inhumed burial, the body lay on its back in an extended position with the legs crossing each other, both the right and the left arms lay parallel to the body. The orientation of the skeleton was NW-SE. Three vessels served as grave goods, all of them were in pieces when the grave was found. The shards of the first urn-like large vessel was found next to the head, and the shards of a beaker were found between the legs. The rest of the pottery belonged to a second urn-like vessel, the position of which in the grave are unknown. Apart from the depth, the dimensions of the grave are unknown (Fig. 2).

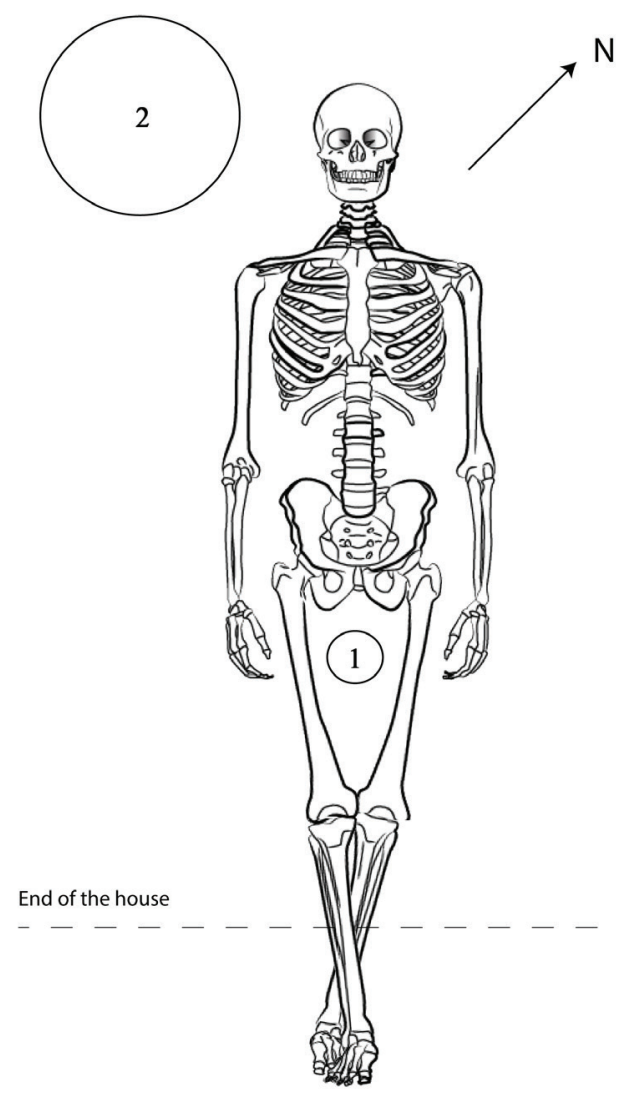

\section{Grave ceramics}

\section{Beaker (Fig. 3.1)}

Material: Handmade ceramic tempered with pebble stones.

Shape: The vessel is biconical with flat bottom and slightly outcurving rim, and it has an asymmetrical shape. A handle is missing but it seems that it was running from the rim to the belly.

Surface: The vessel is polished, the bottom on the outside is reddish brown, and the rest of the vessel is grey on both outside and inside.

Decoration: Around the belly, the beaker is decorated with vertical cannelures.

Dimensions: BD.: 5 cm; MD.: $10.2 \mathrm{~cm}$; RD.: $10 \mathrm{~cm}$; W.: 0.8-1 cm; H.: 7-7.5 cm; HMD.: 3.6 cm. ${ }^{3}$

2. Urn (Fig. 3.2)

Material: Handmade ceramic tempered with pebble stones.

Shape: The vessel is biconical, and it is narrowing from the belly to the flat bottom.

Surface: The bottom on the outside is black, while the colour brown is dominant on the rest of the vessel; both on the inside and the outside. Three rectangular knobs were found, which are sagging from the belly of the urn.

Decoration: The shoulder is decorated with slanted, extremely shallow cannelures; the decoration

1 At this point, I have to thank László Tálas that he gave the finds to the Institute of Archaeological Sciences and I would also like to thank Gábor V. Szabó and Gábor Váczi for their help and the opportunity to present this burial. I thank Kristóf Fülöp, Gábor Váczi, Gábor V. Szabó and András Füzesi for their advices and the restoration of the vessels.

2 The description of the grave is according to the notes of László Tálas.

3 Abbreviations: BD: Bottom diameter, MD.: Maximum diameter, RD.: Rim diameter, W.: width, H.: Height, HMD.: Height of maximum diameter. 
runs around the shoulder but it is not visible everywhere possibly due to erosion.

Dimensions: BD.: $13 \mathrm{~cm}$; MD.: $36 \mathrm{~cm}$; W.: 0.9-1.5 cm; HMD.: $12.2 \mathrm{~cm}$.

3. Urn (Fig. 3.3)

Material: Handmade ceramic tempered with sand and pebble stones.

Shape: The vessel was biconical.

Surface: The outside is mostly black with brownish patches, the inside is brownish-red. There were rectangular knobs among the shards, which were all sagging from the belly of the urn. One vertical cordon was found, which decorated the shoulder.

Decoration: The shoulder is also decorated with slanted cannelures accompanied with finger-impressed dot lines from below and above the cannelures, the neck is decorated with horizontal cannelures and finger-impressed dot lines.

Dimensions: W.: 0.7-1.3; MD.: $41 \mathrm{~cm}$.

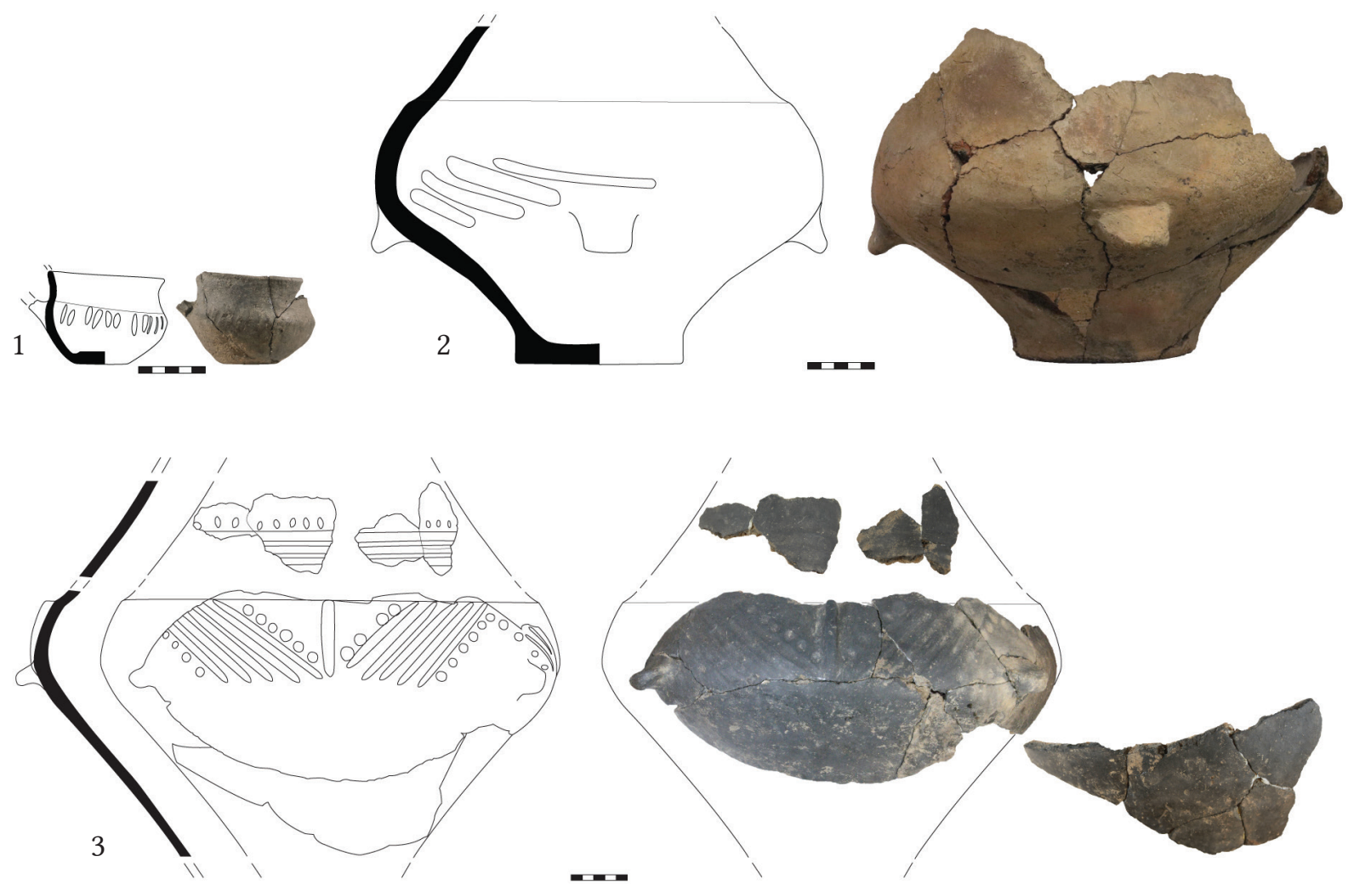

Fig. 3. The grave ceramics: 1 - beaker, 2 - urn, 3 - urn.

\section{Geographical situation}

Burials of the Mezőcsát group are present in Southwestern Slovakia and in the Great Hungarian Plain. ${ }^{4}$ In the Great Hungarian Plain, the Mezőcsát type burials are divided into two groups geographically; one group is at the foot of the North Hungarian Mountains, and the other one is in the Southern Great Plain. ${ }^{5}$ The archaeological sites of the southern group follow the rivers Körös and Maros. However, at the points where the two rivers enter the Tisza River, there are two nodes where the density of the Mezőcsát group sites are higher. These nodes are in the vicinity of Szeged and the vicinity of Csongrád. ${ }^{6}$ Tiszakürt lies close to the latter node (Fig. 4).

4 Romsauer 1999, 167, Abb. 1.

5 Kemenczei 1989, 62.

6 D. Matuz 2000, 149, Abb. 1. 2. 
We have a lot less information about the sites of the southern group of the Great Hungarian Plain than those of the northern one; ${ }^{7}$ the largest, fully excavated cemetery in the Southern Great Plain with its eight graves is Szeged-Algyő. ${ }^{8}$ This cemetery, and possibly all Mezőcsáttype cemeteries belonged to clans or families. ${ }^{9}$ This might allow us the assumption that more graves are hiding in Tiszakürt and waiting to be found, if the expansion of the town in the last century had not destroyed them already. ${ }^{10}$

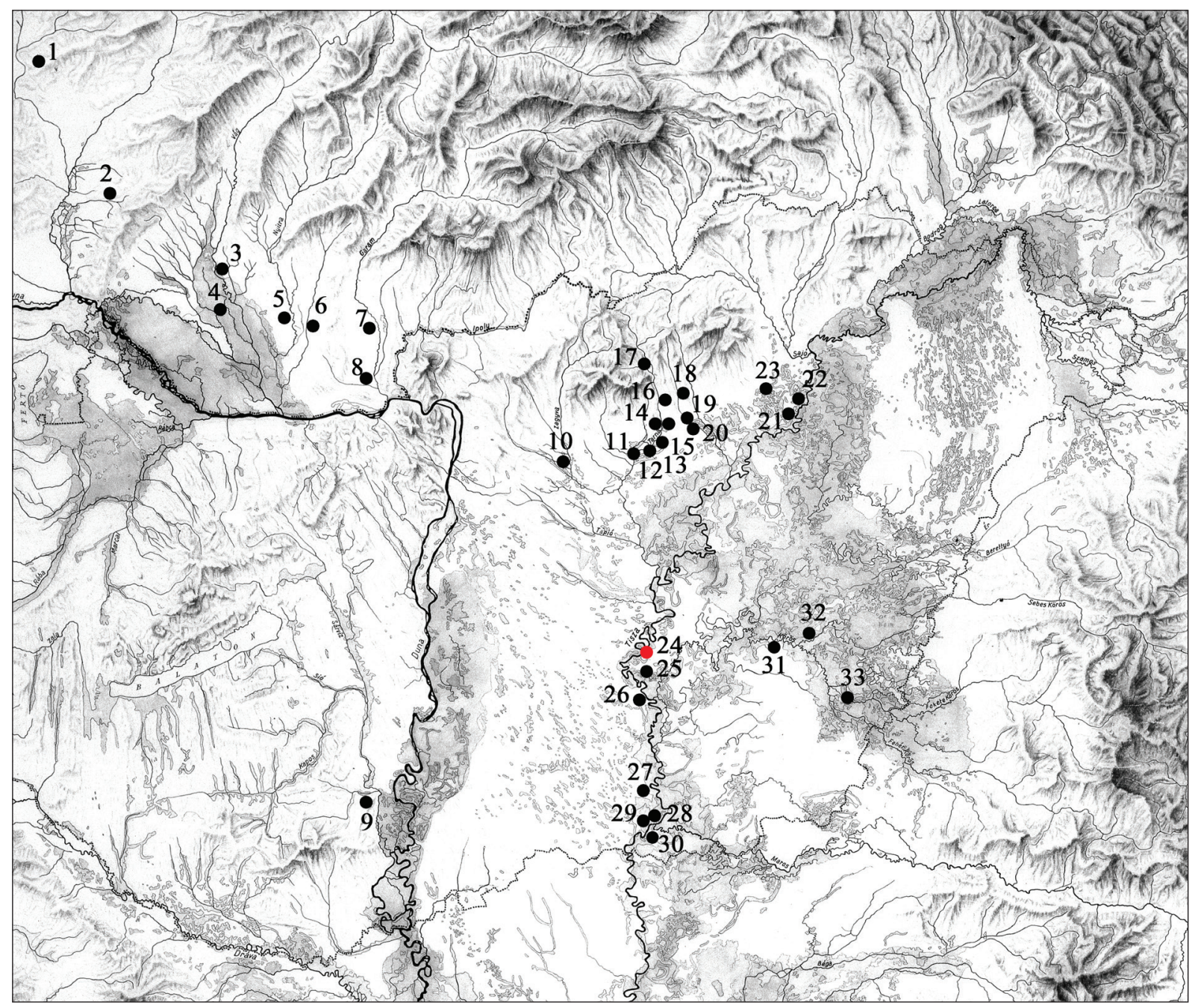

Fig. 4. Burials of the Mezőcsát group (РАтек 1993; Romsauer 1999; D. Matuz 2000). 1 - Podolí-Žuráň, 2 - Senica, 3 - Dvorníky and Dvorníky-Posádka, 4 - Sered, 5 - Ivánka pri Nitre, 6 - Maňa, 7 - Želiezovce, 8 - Salka, 9 - Kakasd, 10 - Hatvan, 11 - Tarnaörs-Csárdamajor and Tarnaörs-Annakápolna, 12 - Boconád, 13 - Tarnabod, 14 - Kompolt-Kígyósér (D. Matuz 2001), 15 - Kál, 16 - Aldebrő, 17 - Sirok-Akasztómály, 18 - Maklár-Koszpérium, 19 - Füzesabony-Kettőshalom and Füzesabony Öregdomb, 20 - Dormánd, 21 - Ároktő-Dongóhalom and Ároktő-Pélypuszta, 22 - Tiszakeszi-Szódadomb, 23 - Mezőcsát-Hörcsögös, 24 - Tiszakürt, 25 - Csépa, 26 - Csongrád-Felgyő, Csongrád-Saroktanya and Csongrád-Vendelhalom, 27 - Szeged-Algyő, 28 - SzegedTápé-Lebő, 29 - Szeged-Öthalom, 30 - Szőreg, 31 - Gyoma, 32 - Körösladány, 33 - Doboz-Maró.

7 Edit D. Matuz summarised the pre-Scythian sites in the Southern Great Plain (D. MATuz 2000, 147-149).

8 D. Matuz 2000, 149

9 Kemenczei 2003, 177.

10 A future excavation is planned to uncover the rest of the grave of Tiszakürt, and further possible graves nearby. 


\section{Grave pottery}

Drinking vessels like cups and beakers were usual grave furnishing materials in the burials of the Mezőcsát group; ${ }^{11}$ beakers with outcurving rims and one handle like the one in Tiszakürt were common. ${ }^{12}$ Some of the beakers of the Mezőcsát group were decorated ${ }^{13}$ in our case a vertical channelled decoration runs around the belly. Chanelled decorations were usual in the Carpathian Basin during the Late Bronze Age ${ }^{14}$ and the Early Iron Age. ${ }^{15}$ These beakers were around in the Great Hungarian Plain before and after the Mezőcsát group. ${ }^{16}$

Another frequent vessel type in the graves of the Mezőcsát group was a large vessel, which appeared in various forms. ${ }^{17}$ In our case, we have two urns, both of which had rectangular knobs sagging from their belly. In the Early Iron Age, these vessels were present from the Dnjester to Northeast Czech Republic. ${ }^{18}$ They were general within the Basarabi complex ${ }^{19}$ during the Hallstatt $C$ period..$^{20}$ Similar urn forms were present west of the Danube ${ }^{21}$ during the last third of the $8^{\text {th }}$ and the first half of the $7^{\text {th }}$ century BC. ${ }^{22}$ Within the Mezőcsát group, a vessel in Ároktő-Dongóhalom shows striking similarities. ${ }^{23}$ It can be dated to the $8^{\text {th } 24}$ or even up to the $9^{\text {th }}$ centuries BC..$^{25}$

The black outside and red inside of the black urn was a common trait of the Late Bronze Age $^{26}$ and Early Iron Age ceramics in the Great Hungarian Plain. ${ }^{27}$ The slanted channelled decoration on the shoulder of the urn was not unusual in the Early Iron Age either. ${ }^{28} \mathrm{We}$ find similar motifs to the one on the black urn, for example in Tarnaörs-Csárdamajor; the neck of that vessel was also decorated but it did not have dot lines. ${ }^{29}$ Finger-impressed dot lines decorated the vessel that contained the horse gears of Fügöd, ${ }^{30}$ which type of decoration was not common within the Mezőcsát group. These finger-impressed dot lines can be found on some ceramic vessels of the Kyjatice culture, ${ }^{31}$ and it was a common decoration of the Urnfield and the Eastern Hallstatt cultures. ${ }^{32}$ The pottery style of the Mezőcsát group

11 Metzner-Nebelsick 1998, 367.

12 Metzner-Nebelsick 1998, Abb. 16-17, 21-22.

13 E.g. Grave 8 in Ároktő-Dongóhalom (Kemenczei 1988a, 91, 2. kép 9) and in Csépa (Kemenczei 1989, 60, Abb. 9. 2).

14 Metzner-Nebelsick 2010, 139; V. Szabó 2017, 233.

15 E.g. Vertical chanelled decorations from Doboz-Marói erdő (GAzDApusztai 1966, 59, Abb. 1).

16 KemenCZEi 2009, 97-98.

17 Metzner-Nebelsick 1998, 367.

18 PARE 1998, 427-428.

19 Vulpe 1965, 108, Abb 5. 6; Vulpe 1986, Abb. 15.

20 Vulpe 1986, 88.

21 Ceramic horizon IIIb. (Metzner-Nebelsick 2002, Abb. 75).

22 Metzner-Nebelsick 2002, 179, Abb. 78.

23 PAtek 1993, 20, Abb. 15. 9.

24 PATEK 1980, 161-162.

25 Patek 1980, 161-162; Pare 1998, 420, 427-428, Tab. 7.

26 Metzner-Nebelsick 2010, 139.

27 Metzner-Nebelsick 1998, 369.

28 Füzesabony-Öregdomb (Gallus - Horváth 1939, 11, Taf. 2. 8), Ároktő-Pélypuszta (Kemenczei 1988a, 92, 3. kép 7), Sirok-Akasztómály (PAтEк 1990, 66, 21. tábla 9), Maklár-Koszpérium (PAтEK 1990, 65, 18. tábla 4), Hódmezővásárhely-Solt-Palé (V. Szabó 1996, 18, 38, Abb. 45. 4).

29 PATEK 1990, 67, 26. tábla 9.

30 Kemenczei 1988b, 68, Abb. 9.

31 Kemenczei 1970, 39.

32 Kemenczei 1974, 11. E.g. Budapest-Békásmegyer (Kalicz-Schreiber et al. 2010, 50-51, Taf. 32. 3) and Nagyberki-Szalacska (Kemenczei 1974, 4, Fig. 2. 2). 
had a contact with all the above-mentioned cultures. ${ }^{33}$ In the Great Hungarian Plain, the channelling and dot line decoration lived on until the Scythian period. ${ }^{34}$

\section{Burial custom}

Comparing with the surrounding cultures in the Late Bronze Age and the Early Iron Age, where cremation was the dominant burial practice,$^{35}$ the inhumed burials of the Mezőcsát group reveal a significant difference; the positioning of the deceased could be either extended or contracted. ${ }^{36}$ Two thirds of the known graves have extended skeletons, like in the grave of Tiszakürt, ${ }^{37}$ while in the Southern Great Plain only one grave was contracted. ${ }^{38}$

Apart from the extended body, the limbs could be situated variously. ${ }^{39}$ In the grave of Tiszakürt, the legs of the deceased were crossed. Although it is not a frequent way to situate the legs, it is not an exception among the Mezőcsát type graves. A further example is in the cemetery of Füzesabony-Kettőshalom. ${ }^{40} \mathrm{We}$ can find more crossed-legged positions like this one dated to the pre-Scythian period in the Eastern European Steppes. ${ }^{41}$ This positioning lived on in the Carpathian Basin until the Middle Iron Age. ${ }^{42}$

Regarding the orientation, $\mathrm{W}-\mathrm{E}$ is the most frequent in the cemeteries of the Mezőcsát group in the Northern Great Plain..$^{43}$ However, there were multiple orientations in one cemetery, and the dominant orientation depends on which cemetery we are looking at. ${ }^{44}$ In Mezőcsát-Hörcsögös the dominant orientation was the above-mentioned W-E, ${ }^{45}$ while in Sirok-Akasztómály the dominant orientation is $\mathrm{NW}-\mathrm{SE},{ }^{46}$ similarly to Tiszakürt.

From the Southern Great Plain we do not have as much data as from the Northern Great Plain. In Szeged Othalom, two grave orientations are known; ${ }^{47}$ one was $\mathrm{S}-\mathrm{N},{ }^{48}$ and the other was E-W-oriented..$^{49}$ In Szeged-Tápé-Lebő, six of the graves were possibly buried during the Early Iron Age, two of them did not contain any grave goods, and the finds from one grave have disappeared. All of these graves were W-E-oriented. ${ }^{50}$ In Szeged-Algyő, five out of the

33 Metzner-Nebelsick 1998, 367-373; Patek 1993, 19; Kemenczei 2005, 120-124; V. Szabó 2017, $256-261$.

34 KAlicz - Koós 1998, 426, 429, Abb. 6. 13.

35 The Gáva culture is an exception, since we do not know what the dominant burial rite was (V. SzABó 2017, 252).

36 Patek 1980, 160; Patek 1990, 70; Kemenczei 1988a, 97; Kemenczei 1989, 70.

37 Szabó 1969, 78; D. Matuz 2001, 45.

38 D. Matuz 2000, 139, Abb. 3. 1; D. Matuz 2001, 45.

39 E.g. In Grave 5 of Sirok-Akasztómály, one arm crossed the body. (PATEK 1990, 66, 34. tábla 4). Another variation was an extended body with bent legs, the left arm crossing the body, and the right arm bent. (PALUCH 2016, 12).

40 PAтек 1990, 64, 31. tábla 4.

41 E.g. Golovkovka in the $9^{\text {th }}$ century ВС (Макновтукн 2008, 243, Рис. 78) and Vysokaja Mogila in the end of the $8^{\text {th }}$ century BC, and the first half of the $7^{\text {th }}$ century ВC (МАкноктүкн 2008, 249, Рис. 71).

42 E.g. Chotín (Kozubová 2013, 44, 68, Obr. 116, 193).

43 PATEK 1990, 70.

44 Metzner-Nebelsick 1998, 363, Abb. 3.

45 PАTEK 1993, 20.

46 PATEK 1990, 66-67.

47 Out of the four graves (PAluch 2016, 13), one contained a disturbed skeleton (Reizner 1904, 81), and the other yielded vessels but no bones (D. MAtuz 2003).

48 VArázséji 1880, 326.

49 Paluch 2016, 12.

50 PÁrducz 1942; Kemenczei 1989, 62. 
eight graves were SW-NE, and three NW-SE-oriented. ${ }^{51}$ In Szőreg, there was a W-E-oriented grave ${ }^{52}$ in Csongrád-Vendelhalom, the grave was NE-SW orientated, ${ }^{53}$ in Csongrád-Saroktanya, there was a SW-NE-oriented grave ${ }^{54}$ the inhumed burial in Csongrád-Felgyő had a WSW-ENE orientation, ${ }^{55}$ and in Doboz, the orientation was E-W. ${ }^{56}$ With its NW-SE orientation, Tiszakürt can be connected to this group. So far, there is no one certain orientation that is present in every site.

Similarly to the orientation, the depth of the graves of the Mezőcsát group also differs from each other; in the cemetery of Mezőcsát-Hörcsögös, most of the graves are at a depth of $30-40 \mathrm{~cm},{ }^{57}$ while in Füzesabony-Kettőshalom, the depth of the graves are beyond $100 \mathrm{~cm}$, sometimes almost reaches $200 \mathrm{~cm} .{ }^{58}$ Our grave was found at a depth of $60-70 \mathrm{~cm}$. A similar depth appears in other graves, like the burial with sidewall niche in Szeged-Öthalom, ${ }^{59}$ and in some graves of Szeged-Algyő. ${ }^{60}$

The vessels in the inhumed graves of the Mezőcsát group are usually placed next to the head or the body, or near the legs.$^{61}$ This means that in Tiszakürt, the brown urn fits into this practice, since it is situated next to the head. The position of the black urn is unknown, and the position of the beaker would be interesting, as it is not common in the graves of the Mezőcsát group. However, the beaker was in pieces, and it is also possible that an animaldisturbed the grave. ${ }^{62}$

\section{Gáva culture, Mezőcsát group or Alföld group}

Throughout my paper, I have been writing about this grave as a burial of the Mezőcsát group, as the burial rite and the grave pottery seemingly support this interpretation. Although one of the main attributes of the Mezőcsát group is the inhumed burial rite, the rite of inhumation can occur before the Early Iron Age, in the Gáva culture, even if it is exceedingly unique. ${ }^{63}$ The channelled decoration is also a characteristic of the Gáva culture.$^{64}$ After the pre-Scythian period, cemeteries of the Alföld group (Vekerzug culture) contained mostly inhumed burials in the Southern Great Plain, ${ }^{65}$ and sometimes vessels resembling those of the pre-Scythian period can appear in Scythian graves. ${ }^{66}$ Moreover, a Scythian pit was discovered not far from our grave, in Tiszakürt-Sziki-Kisföldek. ${ }^{67}$

51 D. Matuz 2000, 149.

52 D. MATuz 2000, 147-148.

53 PÁRduCZ - CSALLÁNy 1945, 89.

54 G. SzÉnÁszky 1972, 6; D. Matuz 2000, 148.

55 PÁrducz 1946, 134. Here, a cremation burial was also dated to the Early Iron Age (PÁrducz 1946, 140).

56 Gazdapusztai 1966, 59.

57 PATEK 1993, 20.

58 PATEK 1990, 62-64.

59 Paluch 2016, 12.

60 Grave 19, Grave 63 (D. Matuz 2000, 139).

61 E.g. Grave 22 of Ároktő-Pélypuszta, vessels placed next to the body (Kemenczei 1988a, 92, 3. kép 5); Grave 8 of Sirok-Akasztómály, vessels placed next to the head (РАTEK 1990, 66-67, 28. tábla 6), Grave 31 of Füzesabony-Kettőshalom, vessels placed next to the legs (РАTEK 1990, 63, 30. tábla 5).

62 Animals have often disturbed graves, e.g. in Graves 53, 82, 83, 85, and 86 of Szeged-Algyő (D. MATUz 2000, 139-141). It could be similar to Grave 3 and Grave 72 in Mezőcsát-Hörcsögös, where the pottery shards were all over the legs of the deceased (PATEK 1993, 145, 147, Abb. 18. 2, 24. 3).

63 KirÁly 2012, 110, 118, P4. 1.

64 V. Szabó 2017, 252.

65 Kemenczei 2001, 15-16.

66 Galántha 1986, 73, Pl. 3. 6.

67 Szilágyi et al. 2017, 394, Fig. 1a. 
The reason for my interpretation, namely that this is a grave of the Mezőcsát group, relies mainly on the temporal appearance of urn forms and the choice of grave ceramics discussed above. The excavation planned to uncover the rest of the grave, and hopefully, to find more, might contradict my interpretation. Until then, it is most likely that the deceased had been laid to rest during the pre-Scythian period of the Great Hungarian Plain.

\section{References}

Galántha, M. 1986: The Scythian Age Cemetery at Csanytelek-Újhalastó. In: Török, L. (Ed.): Hallstatt Kolloquium Veszprém, 1984. Budapest, 69-78.

Gallus, S. - Horváth, T. 1939: A legrégibb lovasnép Magyarországon. A korai vaskorból való régészeti hagyatéka és eurázsiai kapcsolatai (Un peuple cavalier préscythique en Hongrie. trouvailles archéologiques du premier âge du fer et leurs relations avec l'Eurasie). Dissertationes Pannonicae 2/9. Budapest.

Gazdapusztai, Gy. 1966: Das präskytische Grab von Doboz. A Móra Ferenc Múzeum Évkönyve 1. (1964-1965) 59-64.

Kalicz, N. - Koós, J. 1998: Siedlungsfunde der Früheisenzeit aus Ostungarn. In: Hänsle, B. Machnik, J. R. (Eds.): Die Karpatenbecken und die osteuropäische Steppe. Nomadenbewegungen und Kulturaustausch in den vorchristlichen Metallzeiten (4000-500 v.Chr.). Prähistorische Archäologie in Südosteuropa 20/12. München-Rahden/Westf, 423-436.

Kalicz-Schreiber, R. - Kalicz, N. - VÁczi, G. 2010: Ein Gräberfeld der Spätbronzezeit von Budapest-Békásmegyer. Budapest.

Kemenczei, T. 1970: A Kyjatice kultúra Észak-Magyarországon (Die Kyjatice Kultur in Nordungarn). A Hermann Ottó Múzeum Évkönyve 9, 17-78.

Kemenczei, T. 1974: Újabb leletek a nagyberki-szalacskai koravaskori halomsírokról. Archaeologiai Értesitő 101, 3-16.

Kemenczei, T. 1988a: Kora vaskori leletek Dél-Borsodban (Früheisenzeitliche Funde in Süd-Borsod). A Hermann Ottó Múzeum Évkönyve 25-26, 91-105.

Kemenczei, T. 1988b: Der Pferdegeschirrfund von Fügöd. Acta Archaeologica Academiae Scientiarum Hungaricae 40, 65-81.

KemenczeI, T. 1989: Koravaskori sírleletek az Alföldről az Őskori Gyüjteményben (Grabfunde der Früheisenzeit von der Tiefebene in der Prähistorischen Sammlung). Folia Archaeologica 40, 55-74.

Kemenczei, T. 2001: Az Alföld szkíta kora. In: Havassy, P. (Ed.): Hatalmasok viadalokban. Az Alföld szkita kora (Sie sind in Kämpfen Siegreich. Das Zeitalter der Skythen in der Tiefebene). Gyulai katalógusok 10. Gyula, 7-36.

Kemenczei, T. 2003: The beginning of the Iron Age: the pre-Scythians. In: VIsy, Zs. (Ed.): Hungarian archaeology at the turn of the millennium. Budapest, 177-179.

Kemenczei, T. 2005: Funde ostkarpatenländischen Typs im Karpatenbecken. Prähistorische Bronzefunde XX/10. Stuttgart.

Kemenczei, T. 2009: Studien zu den Denkmälern skythisch Geprägter Alföld gruppe. Inverta Praehistorica Hungariae 12. Budapest.

KIRÁly, Á. 2012: A biritual cemetery of the Gáva culture in the Middle Tisza Region and some further notes on the burial customs of the LBA-EIA in Eastern Hungary. In: MARTA, L. (Ed.): The Gáva Culture in the Tisa Plain and Transylvania (Die Gáva-Kultur in der Theißbene und Siebenbürgen). Symposium Satu Mare 17-18 Fune/funi 2011. Studii şi Comunicări - Seria Arheologie 28/1. Satu Mare, 109-132.

KozubovÁ, A. 2013: Pohrebiská Vekerzugskej kultúry v Chotíne na fuhozápadnom Slovensku. Katalóg. Dissertationes archaelogicae Bratislavenses 1. Bratislava. 
МАкноRтүкн, S. 2008: Культура и история киммерийцев северного причерноморья. (Culture and history of the Cimmerians in the Pontic steppes). $\mathrm{PhD}$ thesis. Kiev.

D. MAtuz, E. 2000: A Szeged-Algyő 258. kútkörzet területén feltárt preszkíta temető (Das präskythische Gräberfeld im Brunnenbezirk 258 von Szeged-Algyő). A Móra Ferenc Múzeum Évkönyve Studia Archaeologica 6, 139-164.

D. Matuz, E. 2001: Két preszkíta sír Kompolt-Kígyósérről (Two pre-Scythian burials from Kompolt-Kígyósér). Ösrégészeti Levelek - Prehistoric Newsletter 3, 43-48.

D. Matuz, E. 2003: Preszkíta edények Szeged-Öthalomról (Präskytische Gefäße von Szeged-Öthalom). A Móra Ferenc Múzeum Évkönyve - Studia Archeologica 9, 129-134.

Metzner-Nebelsick, C. 1998: Abschied von den „Thrako-kimmerien“? - Neue Aspekte der Interaktion zwischen karpatenländischen Kulturgruppen der späten Bronze- und frühen Eisenzeit mit der osteuropäischen Steppenkoine. In: Hänsle, B. - Machniк, J. R. (Eds.): Die Karpatenbecken und die osteuropäische Steppe. Nomadenbewegungen und Kulturaustausch in den vorchristlichen Metallzeiten (4000-500 v.Chr.). Prähistorische Archäologie in Südosteuropa 20/12. München-Rahden/Westf, 362-422.

Metzner-Nebelsick, C. 2002: Der „Thrako-Kimmrische” Formenkreis aus der Sicht der Urnenfelderund Hallstattzeit im südöstlichen Pannonien. Vorgeschichtliche Forschungen 23. Leidrof.

Metzner-Nebelsick, C. 2010: Aspects of mobility and in the Eastern Carpathian basin an adjacent areas in the Early Iron Age $\left(10^{\text {th }}-7^{\text {th }}\right.$ centuries BC). In: Dzig̨Gielewski, K. - PrzybyєA, M.S. GAwlik, A. (Eds.): Migration in Bronze and Early Iron Age Europe. Krakow, 121-153.

Paluch, T. 2016: Újabb preszkíta sír Szeged-Öthalmon. Adatok a Kárpát-medence kora vaskori temetkezési szokásaihoz (A new Preschythian grave from Szeged-Öthalom. Data on the Early Iron Age burial customs of the Carpathian Basin). A Móra Ferenc Múzeum Évkönyve - Új folyam 3, $11-23$.

PARE, C. F. E. 1998: Beitrag zum Übergang von der Bronze- zur Eisenzeit in Mitteleuropa. Teil 1: Grundzüge der Chronologie im Östlichen Mitteleuropa (11.-8. Jahrhundert v. Chr.). Jahrbuch des Römisch-Germanischen Zentralmuseums 45, 293-443.

PÁrducz, M. 1942: Preszkíta sírok Lebőn (Praeskythische Gräber in Lebő). Dolgozatok 18, 150-152.

PÁrducz, M. 1946: Csongrádi leletek (Funde in Csongrád). Alföldi Tudományos Intézet Évkönyve 1, 131-148.

PÁrducz, M. - Csallány, D. 1945: Szkítakori leletek a szentesi múzeumban (Funde aus der Skythenzeit im Museum zu Szentes). Archaeologiai Értesitó III/5, 81-117.

Patek, E. 1980: Daten zu den Anfängen der Früheisenzeit in Ungarn. Situla. Dissertationes Musei Nationalis Labacensis 20/21, 153-163.

PAтEK, E. 1990: A Szabó János Győző által feltárt „preszkíta” síranyag. A Füzesabony-Mezőcsát típusú temetkezések újabb emlékei Heves megyében (Die von János Győző Szabó freigelegten "preskythischen" Grabfunde. Die neueren Denkmäler der Bestattungen des Typ Füzesabony Mezőcsát im Komitat Heves). Agria - Az Egri Múzeum Évkönyve 25/26, 61-118.

Patek, E. 1993: Westungarn in der Hallstattzeit. Acta Humaniora 7. Weinheim.

Reizner, J. 1904: Lebői, öthalmi és óbébai ásatások. Archaeologiai Értesitő 24, 76-88.

Romsauer, P. 1999: Zur Frage der Westgrenze der Mezőcsát-Gruppe. In: Jerem, E. - Poroszlai, I. (Eds.): Archaeology of the Bronze Age and Iron Age. Experimental Archaeology, Environmental Archaeology, Archaeological Parks. Proceedings of the International Archaeological Conference. Százhalombatta, 3-7 October 1996. Budapest, 167-176.

SzABó, J. Gy. 1969: A hevesi szkítakori temető. Hozzászólás az Alföld szkítakori népességének kérdéséhez (Das Gräberfeld von Heves aus der Skythenzeit. Beitrag zum Problem der Population des Ung. Tieflandes in der Skythenzeit). Agria - Az Egri Múzeum Évkönyve 7, 55-128.

V. SzABó, G. 1996: A Csorva-csoport és a Gáva-kultúra kutatásának problémái néhány Csongrád megyei leletegyüttes alapján (Forschungsbprobleme der Csorva-gruppe und der Gáva-kultur 
aufgrund einiger Fundverbände aus dem Komitat Csongrád). A Móra Ferenc Múzeum Évkönyve Studia Archaeologica 2, 9-109.

V. SzABó, G. 2017: A Gáva-kerámiastílus kora. Az Alföld a hajdúböszörményi szitulák földbekerülésének időszakában (The age of the Gáva pottery style. The Great Hungarian Plain in the time of the burying of the Hajdúböszörmény situlae). In: V. SzABó, G. - BÁlint, M. - VÁczI, G. (Eds.): A második hajdúböszörményi szitula és kapcsolatrendszere (The second situla of $\mathrm{Ha}$ júbböszörmény and its relations). Studia Oppidorum Haidonicalium XIII. Budapest-Hajdúböszörmény, 231-278.

G. SzÉnÁszky, J. 1972: Csongrád-Saroktanya. Régészeti Füzetek I. 1/25, 6.

Szilágyi, M. - Fülöp, K. - RÁkos, E. - Szabó, N. 2017: Rescue excavations in the vicinity of Cserkeszőlő (Jász-Nagykun-Szolnok county, Hungary) in 2017. Dissertationes Archaeologicae 3/5, 393-400.

VArÁzsÉji, G. 1880: A Szeged-öthalmi őstelep és temető. Archaeologiai Értesitő 14, 323-336

Vulpe, A. 1965: Zur mittleren Hallstattzeit in Rumänien (Die Basarabi Kultur). Dacia. Revoue d'Archéologie et d'Historie Ancienne 9, 105-132.

Vulpe, A. 1986: Zur Entstehung der Geto-Drakischen Zivilisation. Die Basarabi kultur. Dacia. Revoue d'Archéologie et d'Historie Ancienne 30, 49-89. 